

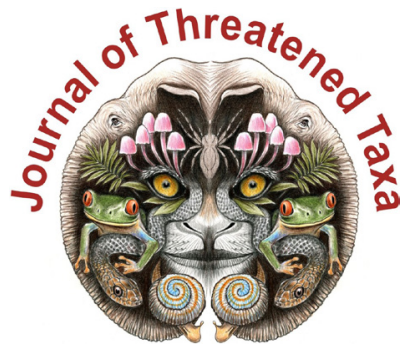

ISSN 0974-7907 (Online); ISSN $0974-7893$ (Print)

Publisher

Host

Wildlife Information Liaison Development Society

www.wild.zooreach.org

Zoo Outreach Organization www.zooreach.org

No. 12, Thiruvannamalai Nagar, Saravanampatti - Kalapatti Road, Saravanampatti, Coimbatore, Tamil Nadu 641035, India

Ph: +91 9385339863 | www.threatenedtaxa.org

Email: sanjay@threatenedtaxa.org

EDITORS

\section{Founder \& Chief Editor}

Dr. Sanjay Molur

Wildlife Information Liaison Development (WILD) Society \& Zoo Outreach Organization (ZOO),

12 Thiruvannamalai Nagar, Saravanampatti, Coimbatore, Tamil Nadu 641035, India

\section{Deputy Chief Editor}

Dr. Neelesh Dahanukar

Noida, Uttar Pradesh, India

\section{Managing Editor}

Mr. B. Ravichandran, WILD/ZOO, Coimbatore, India

\section{Associate Editors}

Dr. Mandar Paingankar, Government Science College Gadchiroli, Maharashtra 442605, India

Dr. Ulrike Streicher, Wildlife Veterinarian, Eugene, Oregon, USA

Ms. Priyanka Iyer, ZOO/WILD, Coimbatore, Tamil Nadu 641035, India

Dr. B.A. Daniel, ZOO/WILD, Coimbatore, Tamil Nadu 641035, India

\section{Editorial Board}

Dr. Russel Mittermeier

Executive Vice Chair, Conservation International, Arlington, Virginia 22202, USA

\section{Prof. Mewa Singh Ph.D., FASc, FNA, FNASc, FNAPsy}

Ramanna Fellow and Life-Long Distinguished Professor, Biopsychology Laboratory, and Institute of Excellence, University of Mysore, Mysuru, Karnataka 570006, India; Honorary Professor, Jawaharlal Nehru Centre for Advanced Scientific Research, Bangalore; and Adjunct Professor, National Institute of Advanced Studies, Bangalore

\section{Stephen D. Nash}

Scientific Illustrator, Conservation International, Dept. of Anatomical Sciences, Health Sciences Center, T-8, Room 045, Stony Brook University, Stony Brook, NY 11794-8081, USA

\section{Dr. Fred Pluthero}

Toronto, Canada

\section{Dr. Priya Davidar}

Sigur Nature Trust, Chadapatti, Mavinhalla PO, Nilgiris, Tamil Nadu 643223, India

\section{Dr. Martin Fisher}

Senior Associate Professor, Battcock Centre for Experimental Astrophysics, Cavendish

Laboratory, JJ Thomson Avenue, Cambridge CB3 OHE, UK

\section{Dr. John Fellowes}

Honorary Assistant Professor, The Kadoorie Institute, 8/F, T.T. Tsui Building, The University of Hong Kong, Pokfulam Road, Hong Kong

\section{Prof. Dr. Mirco Solé}

Universidade Estadual de Santa Cruz, Departamento de Ciências Biológicas, Vice-coordenado do Programa de Pós-Graduação em Zoologia, Rodovia Ilhéus/Itabuna, Km 16 (45662-000)

Salobrinho, Ilhéus - Bahia - Brasil

\section{Dr. Rajeev Raghavan}

Professor of Taxonomy, Kerala University of Fisheries \& Ocean Studies, Kochi, Kerala, India

\section{English Editors}

Mrs. Mira Bhojwani, Pune, India

Dr. Fred Pluthero, Toronto, Canad

Mr. P. Ilangovan, Chennai, India

Web Development

Mrs. Latha G. Ravikumar, ZOO/WILD, Coimbatore, India

\section{Typesetting}

Mr. Arul Jagadish, ZOO, Coimbatore, India

Mrs. Radhika, ZOO, Coimbatore, India

Mrs. Geetha, ZOO, Coimbatore India
Fundraising/Communications

Mrs. Payal B. Molur, Coimbatore, India

Subject Editors 2018-2020

Fungi

Dr. B. Shivaraju, Bengaluru, Karnataka, India

Dr. R.K. Verma, Tropical Forest Research Institute, Jabalpur, India

Dr. Vatsavaya S. Raju, Kakatiay University, Warangal, Andhra Pradesh, India

Dr. M. Krishnappa, Jnana Sahyadri, Kuvempu University, Shimoga, Karnataka, India

Dr. K.R. Sridhar, Mangalore University, Mangalagangotri, Mangalore, Karnataka, India

Dr. Gunjan Biswas, Vidyasagar University, Midnapore, West Bengal, India

\section{Plants}

Dr. G.P. Sinha, Botanical Survey of India, Allahabad, India

Dr. N.P. Balakrishnan, Ret. Joint Director, BSI, Coimbatore, India

Dr. Shonil Bhagwat, Open University and University of Oxford, UK

Prof. D.J. Bhat, Retd. Professor, Goa University, Goa, India

Dr. Ferdinando Boero, Università del Salento, Lecce, Italy

Dr. Dale R. Calder, Royal Ontaro Museum, Toronto, Ontario, Canada

Dr. Cleofas Cervancia, Univ. of Philippines Los Baños College Laguna, Philippines

Dr. F.B. Vincent Florens, University of Mauritius, Mauritius

Dr. Merlin Franco, Curtin University, Malaysia

Dr. V. Irudayaraj, St. Xavier's College, Palayamkottai, Tamil Nadu, India

Dr. B.S. Kholia, Botanical Survey of India, Gangtok, Sikkim, India

Dr. Pankaj Kumar, Kadoorie Farm and Botanic Garden Corporation, Hong Kong S.A.R., China

Dr. V. Sampath Kumar, Botanical Survey of India, Howrah, West Bengal, India

Dr. A.J. Solomon Raju, Andhra University, Visakhapatnam, India

Dr. Vijayasankar Raman, University of Mississippi, USA

Dr. B. Ravi Prasad Rao, Sri Krishnadevaraya University, Anantpur, India

Dr. K. Ravikumar, FRLHT, Bengaluru, Karnataka, India

Dr. Aparna Watve, Pune, Maharashtra, India

Dr. Qiang Liu, Xishuangbanna Tropical Botanical Garden, Yunnan, China

Dr. Noor Azhar Mohamed Shazili, Universiti Malaysia Terengganu, Kuala Terengganu, Malaysia

Dr. M.K. Vasudeva Rao, Shiv Ranjani Housing Society, Pune, Maharashtra, India

Prof. A.J. Solomon Raju, Andhra University, Visakhapatnam, India

Dr. Mandar Datar, Agharkar Research Institute, Pune, Maharashtra, India

Dr. M.K. Janarthanam, Goa University, Goa, India

Dr. K. Karthigeyan, Botanical Survey of India, India

Dr. Errol Vela, University of Montpellier, Montpellier, France

Dr. P. Lakshminarasimhan, Botanical Survey of India, Howrah, India

Dr. Larry R. Noblick, Montgomery Botanical Center, Miami, USA

Dr. K. Haridasan, Pallavur, Palakkad District, Kerala, India

Dr. Analinda Manila-Fajard, University of the Philippines Los Banos, Laguna, Philippines

Dr. P.A. Sinu, Central University of Kerala, Kasaragod, Kerala, India

Dr. Afroz Alam, Banasthali Vidyapith (accredited A grade by NAAC), Rajasthan, India

Dr. K.P. Rajesh, Zamorin's Guruvayurappan College, GA College PO, Kozhikode, Kerala, India

Dr. David E. Boufford, Harvard University Herbaria, Cambridge, MA 02138-2020, USA

Dr. Ritesh Kumar Choudhary, Agharkar Research Institute, Pune, Maharashtra, India

Dr. Navendu Page, Wildlife Institute of India, Chandrabani, Dehradun, Uttarakhand, India

\section{Invertebrates}

Dr. R.K. Avasthi, Rohtak University, Haryana, India

Dr. D.B. Bastawade, Maharashtra, India

Dr. Partha Pratim Bhattacharjee, Tripura University, Suryamaninagar, India

Dr. Kailash Chandra, Zoological Survey of India, Jabalpur, Madhya Pradesh, India

Dr. Ansie Dippenaar-Schoeman, University of Pretoria, Queenswood, South Africa

Dr. Rory Dow, National Museum of natural History Naturalis, The Netherlands

Dr. Brian Fisher, California Academy of Sciences, USA

Dr. Richard Gallon, llandudno, North Wales, LL30 1UP

Dr. Hemant V. Ghate, Modern College, Pune, India

Dr. M. Monwar Hossain, Jahangirnagar University, Dhaka, Bangladesh

Mr. Jatishwor Singh Irungbam, Biology Centre CAS, Branišovská, Czech Republic.

Dr. Ian J. Kitching, Natural History Museum, Cromwell Road, UK

Dr. George Mathew, Kerala Forest Research Institute, Peechi, India

For Focus, Scope, Aims, and Policies, visit https://threatenedtaxa.org/index.php/JoTT/aims_scope
For Article Submission Guidelines, visit https://threatenedtaxa.org/index.php/JoTT/about/submissions
For Policies against Scientific Misconduct, visit https://threatenedtaxa.org/index.php/JoTT/policies_various

continued on the back inside cover 


\title{
Successful rescue, medical management, rehabilitation, and translocation of a Red Panda Ailurus fulgens (Mammalia: Carnivora: Ailuridae) in Arunachal Pradesh, India
}

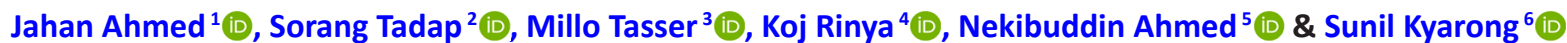 \\ ${ }^{1}$ College of Veterinary Science, Assam Agricultural University, Guwahati, Assam 781022, India. \\ ${ }^{2}$ Biological Park, Itanagar, Arunachal Pradesh 791111, India. \\ ${ }^{3,4}$ Department of Environment, Forest and Climate Change, Arunachal Pradesh 791111, India. \\ ${ }^{5}$ Lakhimpur College of Veterinary Science, Assam Agricultural University, North Lakhimpur, Assam 787051, India. \\ ${ }^{6}$ Wildlife Trust of India, F-13, Sector 8, National Capital Region (NCR), Noida 201301, India. \\ 1.jahan.ahmed6@gmail.com, ${ }^{2}$ sorangtadap@gmail.com, ${ }^{3}$ tasser.m@gmail.com, ${ }^{4}$ dfoziro@gmail.com, \\ ${ }^{5}$ nekibahmeds@gmail.com (corresponding author), ${ }^{6}$ sunil@wti.org.in
}

Abstract: We document the rescue of a Red Panda from Yachuli circle, Lower Subansiri district and successful translocation to Eaglenest Wildlife Sanctuary, West Kameng district of Arunachal Pradesh, India. The head injury was surgically managed under the anaesthetic combination of ketamine and xylazine, and reversed with yohimbine. The animal was successfully rehabilitated and translocated in the Eaglenest Wildlife Sanctuary.

Keywords: Ailuridae, Anaesthetic combination, Eaglenest Wildlife Sanctuary, head injury, translocate, Yachuli circle.

Red Panda Ailurus fulgens is the only living member of the genus Ailurus and the family Ailuridae. Its present natural home range in India includes the states of Sikkim, West Bengal (Darjeeling district), and Arunachal Pradesh (Glatston et al. 2015). The largest population is in Arunachal Pradesh (Choudhury 2001), and it has been rapidly declining due to habitat loss \& fragmentation, poaching, and inbreeding depression (Glatston et al. 2015). Based on the population estimate, the International Union for Conservation of Nature (IUCN) Red List of Threatened Species 2015 has listed the Red Panda under the 'Endangered' species category (Glatston et al. 2015). There is limited information on its management in captivity and use of anaesthesia for surgical interventions (Jha 2014). This paper documents the chance rescue of a Red Panda from Yachuli circle of Lower Subansiri district, its management in captivity and translocation to Eaglenest Wildlife Sanctuary, West Kameng district of Arunachal Pradesh, India. Panda Ailurus fulgens (Mammalia: Carnivora: Ailuridae) in Arunachal Pradesh, India. Journal of Threatened Taxa 13(13): 20066-20071. https://doi.org/10.11609/ jott.6679.13.13.20066-20071

Copyright: (C) Ahmed et al. 2021. Creative Commons Attribution 4.0 International License. JoTT allows unrestricted use, reproduction, and distribution of this article in any medium by providing adequate credit to the author(s) and the source of publication.

Funding: Department of Environment, Forest and Climate Change, Arunachal Pradesh, India and International Fund for Animal Welfare (IFAW)-Wildlife Trust of India (WTI).

Competing interests: The authors declare no competing interests.

Acknowledgements: All the authors thank Mr. Taba Nepa, Block Educational Officer, Kebi panchayat for rescuing the endangered species and transferring the animal to the Biological Park, Itanagar all by himself. Mr. Nepa contacted Mr. Bunty Tao, Range Forest Officer, Raga, Hapoli Forest Division, who facilitated and liaised for smooth transferring of the Red Panda to the Biological Park, Itanagar. The authors are thankful to the Department of Environment, Forest and Climate Change, Government of Arunachal Pradesh, Centre for Bear Rehabilitation and Conservation (CBRC) Seijosa, Executive Director, Wildlife Trust of India, Director, Biological Park, Itanagar, Divisional Forest Officer, Pakke Tiger Reserve, Range Forest Officers namely Kushal Hazarika, Rayo Flago, Kime Rambia of Department of Environment and Forest for all the help rendered in the care and treatment of Red Panda. Thanks are also due to Mr. Indi Glow for his help and suggestions. It would be inadequate if the name of Animal keeper Mr. Birkhe Bahadur is not mentioned. He took all the care and responsibility of the animal during translocation. Thanks are also due to the staffs of Biological park, Itanagar for helping in taking care of the Red Panda during admission into the zoo facility. 


\section{Case description}

Mr. Taba Nepa, a Block Educational Officer in profession of Kebi village under the Yachuli circle, Lower Subansiri district of Arunachal Pradesh encountered an injured male Red Panda in his agricultural field on 6th February, 2016. He rescued the animal and informed the local veterinarian on the next day for veterinary care. After providing first aid, further contact was made with the officials at the Biological Park, Itanagar, Arunachal Pradesh for better health management of the animal. The animal was handed over to the wildlife veterinarian at the Park on 8th February at around 22.00 hours for further treatment and rehabilitation.

\section{RESULTS}

\section{Clinical findings}

At arrival in the Biological Park, the weight of the animal was recorded as $5 \mathrm{~kg}$. It had very feeble body movement, unresponsiveness to external stimuli, and dyspnoea. There was a visible swelling on the left side of the axis of head near the zygomatic process, with a laceration over the lateral canthus of the left eye which required suturing. The animal was moderately dehydrated owing to anorexia which was ascribed to the injury, followed by pain and stress during transportation. Based on overall clinical status we assessed the condition as critical necessitating emergency veterinary care.

\section{Veterinary care}

A whole body radiographic investigation revealed no evidence of skeletal damage (Image 1). The cut injury was cleaned with antiseptic solution and topical antibiotic ointment was applied. The animal was immediately put under treatment with parenteral long acting antibiotic [enrofloxacin@ 07.5 mg/kg body weight i.m. (Fortivir, Virbac Animal Health India Pvt. Ltd.)], NSAID [nimesulide @ $5 \mathrm{mg} / \mathrm{kg}$ body weight i.m. (Nimovet, Indian Immunologicals Ltd.)], steroid [Dexamethasone @ 2 mg i.m. [Dexona, Zydus Animal Health Ltd.)], liver supportive [@5 ml orally (Liv.52, The Himalaya Drug Company)] and multivitamin supplement [@ $5 \mathrm{ml}$ orally (Intacal Pet, Intas Pharmaceuticals Ltd.)]. The condition was monitored at every hour. After 24 hours of medication and care, there was improvement in the body condition, evidenced by physical movement and slight responses to external stimuli. The treatment regime was continued for seven days with a daily recommended diet as practiced elsewhere (Padmaja Naidu Himalayan Zoological Park, Darjeeling, West Bengal, India). Initially, the feeding schedule was divided into three times a day (morning, afternoon and evening). Gradually the frequency was

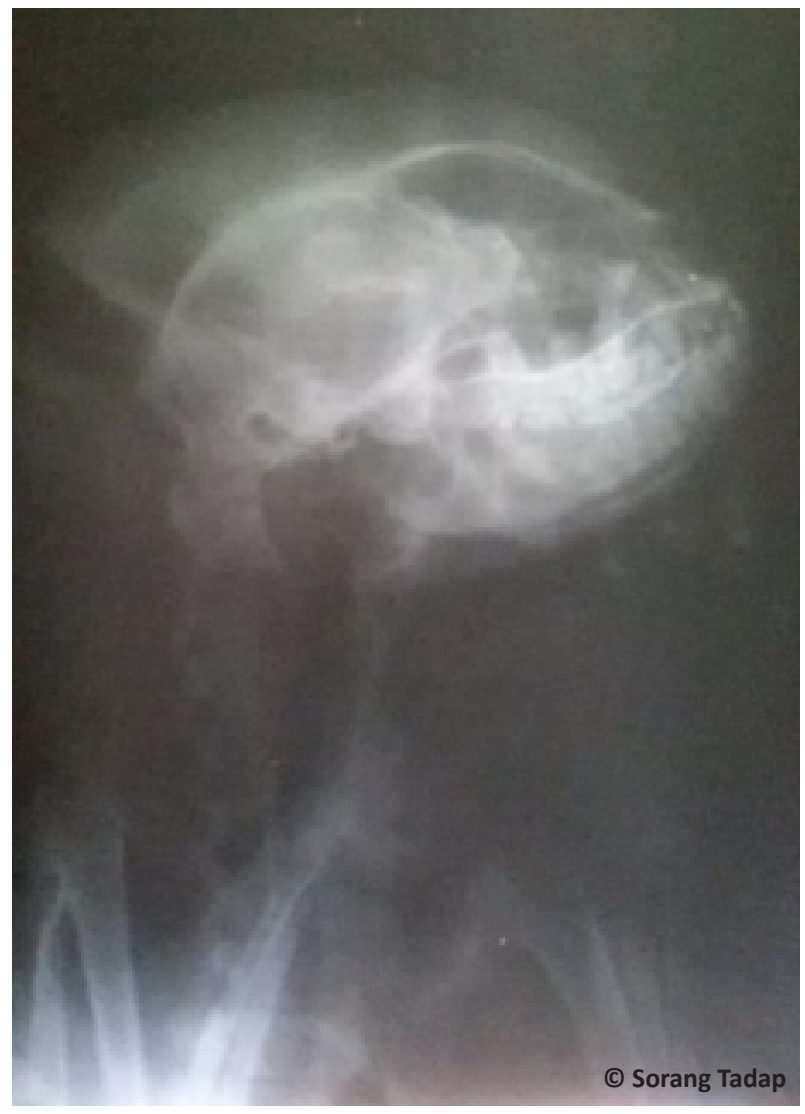

Image 1. Radiographic image of Red Panda skull.

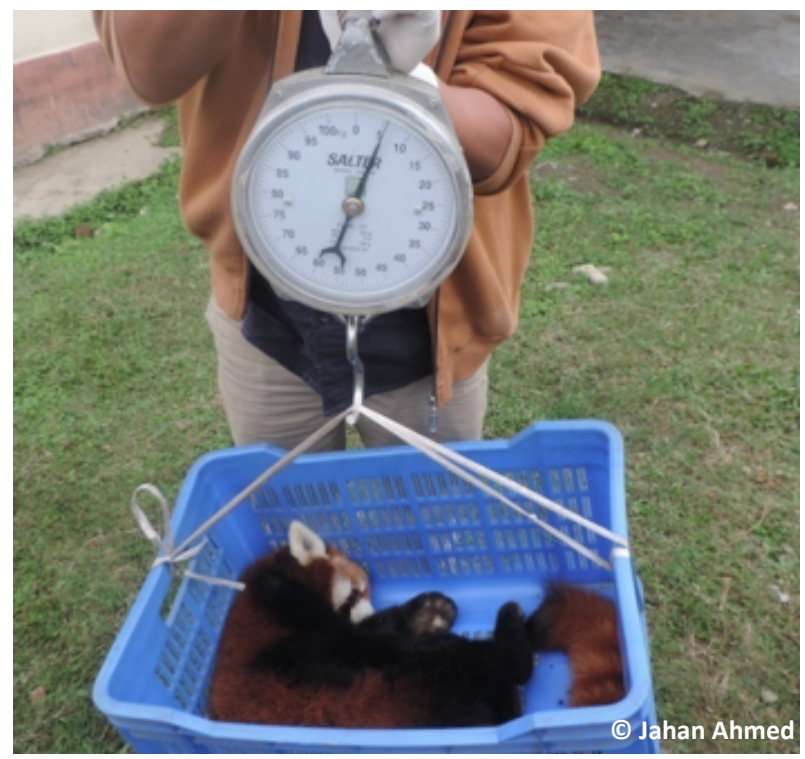

Image 2. Weighing of the Red Panda.

narrowed down to twice a day (morning and evening) and then once daily (evening) as the Red Panda is a nocturnal animal. The diet composition was gradually substituted to its natural diet, i.e., bamboo leaves and 
Table 1. Diet composition of Red Panda.

\begin{tabular}{|l|c|}
\hline Constituents & Quantity \\
\hline Milk & $200 \mathrm{ml}$ \\
\hline Honey & $20 \mathrm{ml}$ \\
\hline Banana & $1 \mathrm{no}$. \\
\hline Apple & $200 \mathrm{~g}$ \\
\hline Bamboo shoots and leaves & $4 \mathrm{~kg}$ \\
\hline Raw egg & $1 \mathrm{no}$. \\
\hline Drinking water & $1 \mathrm{l}$ \\
\hline
\end{tabular}

Table 2. Data of vital parameters during anaesthesia.

\begin{tabular}{|l|l|}
\hline Parameters & Recorded data \\
\hline Body temperature & $37.6^{\circ} \mathrm{C}$ \\
\hline Heart rate & 93 beats $/ \mathrm{min}$ \\
\hline Respiratory rate & 21 breathes/min \\
\hline Ocular reflex & Present \\
\hline
\end{tabular}

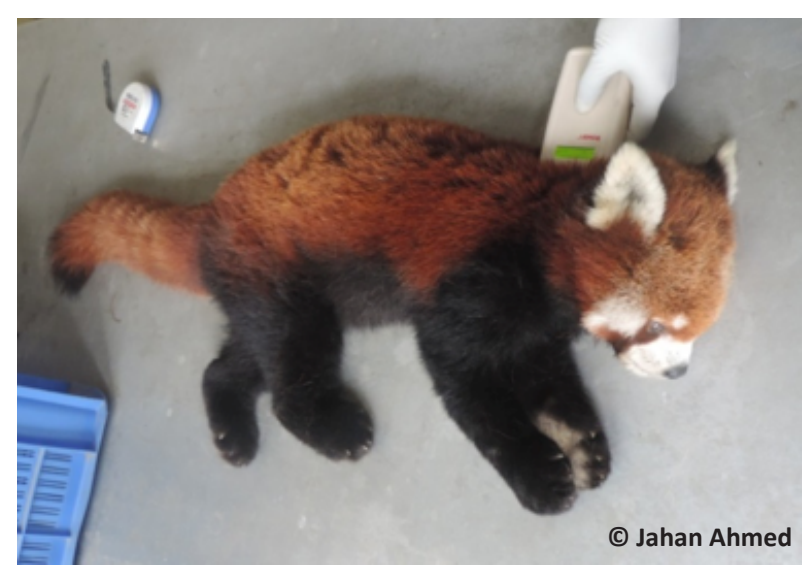

Image 3. Red Panda in lateral recumbency under anesthesia.

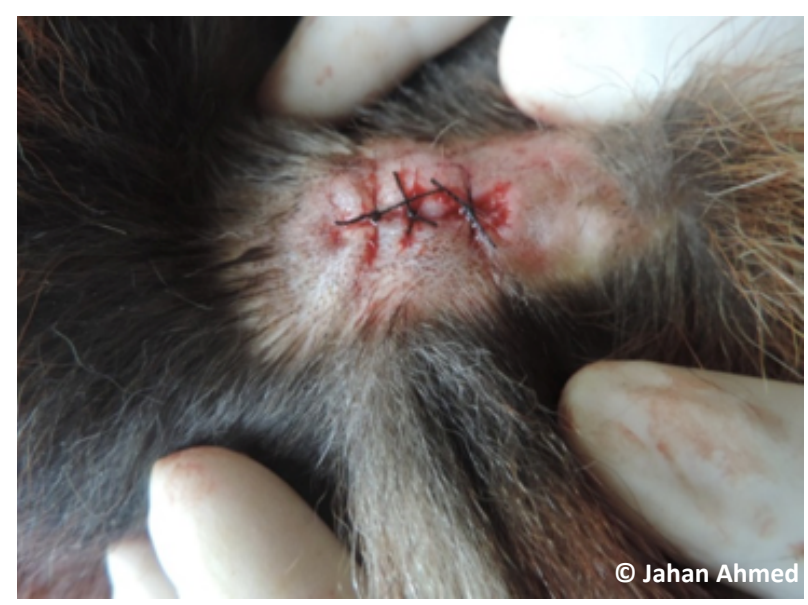

Image 4. Suturing of the skin with black braided silk. shoots by decreasing the feeding of supplements (Table 1). There was significant recuperation on a daily basis after hospitalization in the Park facility. The swelling on the head subsided. After two weeks of hospitalization, the Red Panda was administered with albendazole @ $25 \mathrm{mg} / \mathrm{kg}$ b.w. orally (Wormer Vet, Legend Remedies Pvt. Ltd.) for three consecutive days along with liver supportive supplement @ $5 \mathrm{ml}$ orally (Liv.52, The Himalaya Drug Company). On the $3^{\text {rd }}$ week the Red Panda was vaccinated against Rabies virus @ $1 \mathrm{ml}$ intramuscular (Raksharab, Indian Immunologicals Ltd.) to be followed by a booster after one month, thereafter to be repeated annually.

As the clinical condition was significantly improved, the animal had to be translocated to a rehabilitation facility located at the Eaglenest Wildlife Sanctuary in the West Kameng district, which is $290 \mathrm{~km}$ west from the Biological Park. Prior to translocation a thorough health check-up was warranted. This demanded sedation of the animal on $32^{\text {nd }}$ day of hospitalization.

\section{Preoperative, operative and post-operative procedures}

Before sedation, food and water was withheld for 12 hours. Weight of the animal was recorded to be $5 \mathrm{~kg}$ (Image 2). Accordingly, two anaesthetics were selected for intramuscular administration, i.e., ketamine $\mathrm{HCl}$ and xylazine $\mathrm{HCl}$ combination @ $10 \mathrm{mg} / \mathrm{kg}$ b.w. and $0.4 \mathrm{mg} /$ $\mathrm{kg}$ b.w., respectively. The drug induction and down time was at three and seven minutes after administration of anaesthesia, respectively (Image 3). The vital parameters of the animal were recorded (Table 2). Anaesthesia was maintained for 25 minutes to complete suturing of the wound.

During complete sedation, the lacerated wound was cleaned with non-irritant antiseptic. The lesion was closed with simple interrupted sutures (Image 4). Postoperatively, it was medicated with antibiotic [Ceftriaxone @ $20 \mathrm{mg} / \mathrm{kg}$ body weight (Intacef, Intas Pharmaceuticals Ltd.)], NSAID [Meloxicam @ 0.2 mg/kg body weight (Melonex, Intas Pharmaceuticals Ltd.)] with multivitamin supplement (Tribivet, Intas Pharmaceuticals Ltd.) to be continued for five consecutive days. Once the post-operative procedures were accomplished, different physical and physiological parameters were recorded (Image 5, 6; Table 3, 4) and a microchip was implanted with No - 961001000005995 subcutaneous on the left side of the neck region (Image 7).

\section{Anaesthetic reversal}

As reversal, yohimbine $\mathrm{HCl} @ 0.4 \mathrm{mg} / \mathrm{kg}$ b.w., i.m. was selected. Recovery was completed in 14 minutes of 


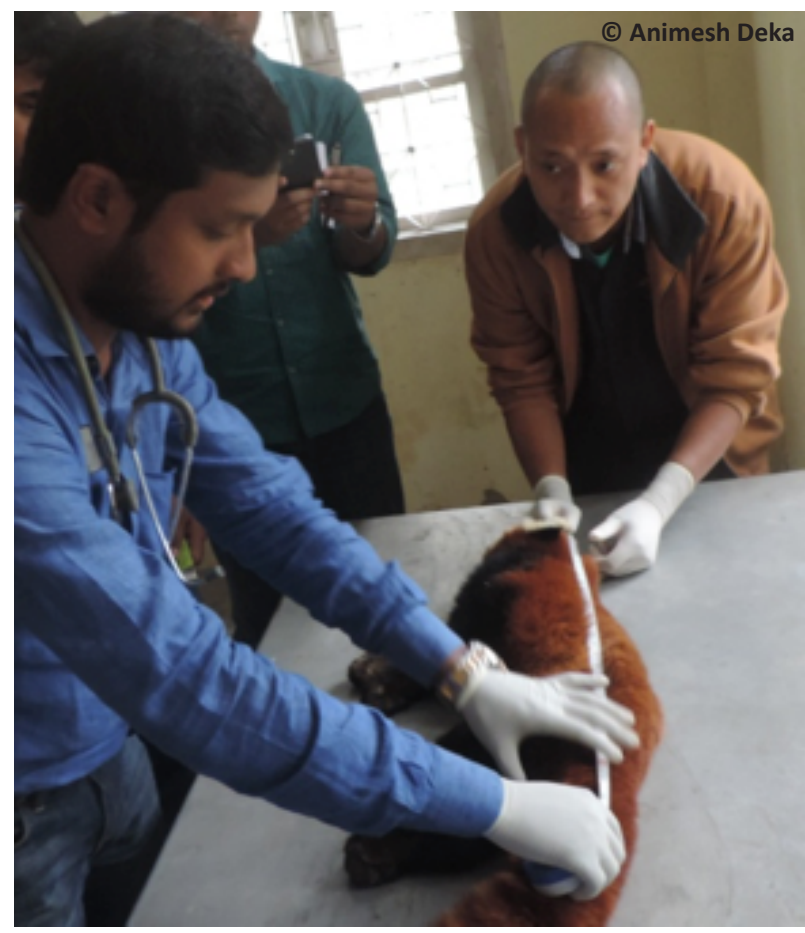

Image 5. Measuring of the Red Panda.

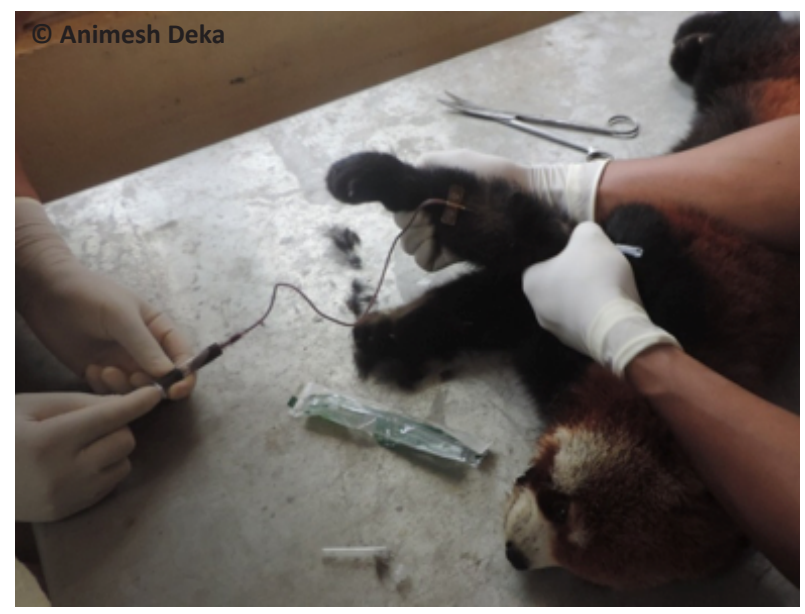

Image 6. Blood collection from cephalic vein.

reversal administration

\section{Translocation and rehabilitation}

For transportation of the animal to the rehabilitation facility, a cage was prepared (Image 8) by mobile veterinary service unit of the Wildlife Trust of India (WTI). On the $41^{\text {st }}$ day of hospitalization the animal was successfully translocated and rehabilitated in the Eaglenest Wildlife Sanctuary into a separate enclosure (Image 9). The enclosure was cuboidal in shape,
Table 3. Mean physical measurements of body

\begin{tabular}{|l|c|}
\hline Parameters & Length \\
\hline Length from nostril to base of tail & $68.5 \mathrm{~cm}$ \\
\hline Length of tail (base to tip) & $42 \mathrm{~cm}$ \\
\hline Neck girth & $23 \mathrm{~cm}$ \\
\hline Height of fore leg & $20.5 \mathrm{~cm}$ \\
\hline Height of hind leg & $20.5 \mathrm{~cm}$ \\
\hline
\end{tabular}

Table 4. Haematological and biochemical parameters

\begin{tabular}{|l|c|}
\hline Parameter & Value \\
\hline Haemoglobin (g/dl) & 12.5 \\
\hline Glucose $(\mathrm{mg} / \mathrm{dl})$ & 75.5 \\
\hline Total protein (g/dl) & 6.8 \\
\hline Alkaline phosphatase (IU/L) & 35.8 \\
\hline Asparatate aminotransferase (IU/L) & 74.5 \\
\hline Alanine aminotransferase (IU/L) & 77.1 \\
\hline Total bilirubin (mg/dl) & 0.3 \\
\hline Creatinine (mg/dl) & 0.8 \\
\hline
\end{tabular}

measured 60 feet in diameter and height of 12 feet at the periphery and 17 feet in the centre. There was a refuge den which was covered inside the enclosure with facility for watering and feeding (Image 10).

\section{Discussion}

The present episode reveals a sustained rescue operation of an injured individual from an endangered (IUCN Red List of Threatened Species 2015) and Schedule-I species (Wildlife Protection Act, 1972 ) from Yachuli circle of Lower Subansiri district, its successful veterinary care with translocation and rehabilitation effort to Eaglenest Wildlife Sanctuary in the West Kameng district of Arunachal Pradesh, India. Red Pandas have been recorded from 11 districts of Arunachal Pradesh: Changlang, Dibang Valley, East Kameng, East Siang, Lohit, Lower Subansiri, Upper Siang, Upper Subansiri, West Kameng, West Siang and Tawang (Choudhury 2001; Chakraborty et al. 2015). Clandestine wildlife poaching and illegal trade is rampant worldwide wherever there is rich biodiversity. Under what circumstances the present Red Panda was rescued from its habitat is unclear, but the presence of traumatic swelling on head and the laceration was possible indication of a malicious attempt on its life. However, adequate veterinary care and medication in time could sustain its life. The treatment and feeding schedule with feed ingredients were found effective which progressively restored the animal's 


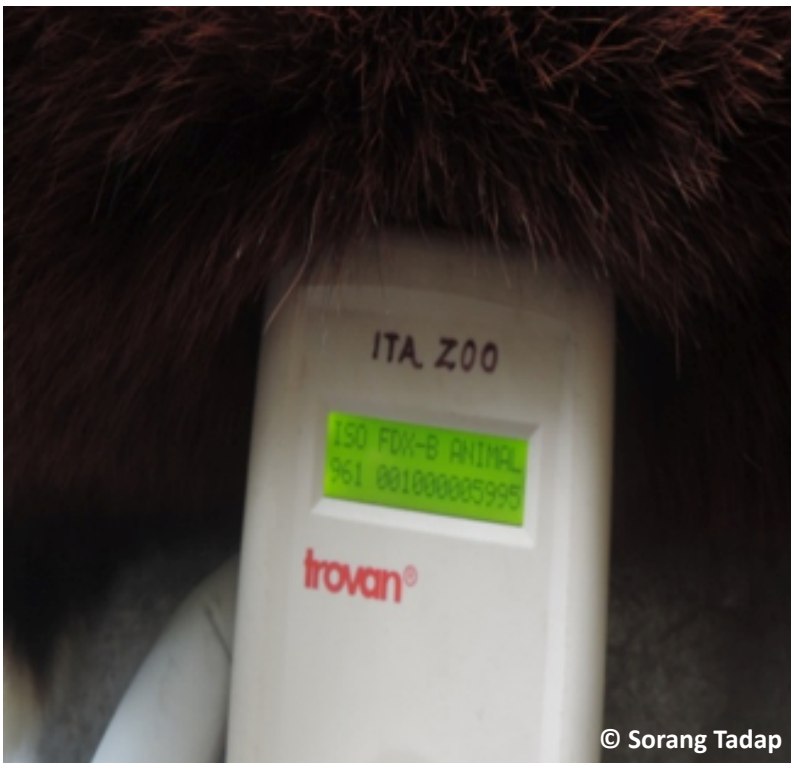

Image 7. Microchip reading.

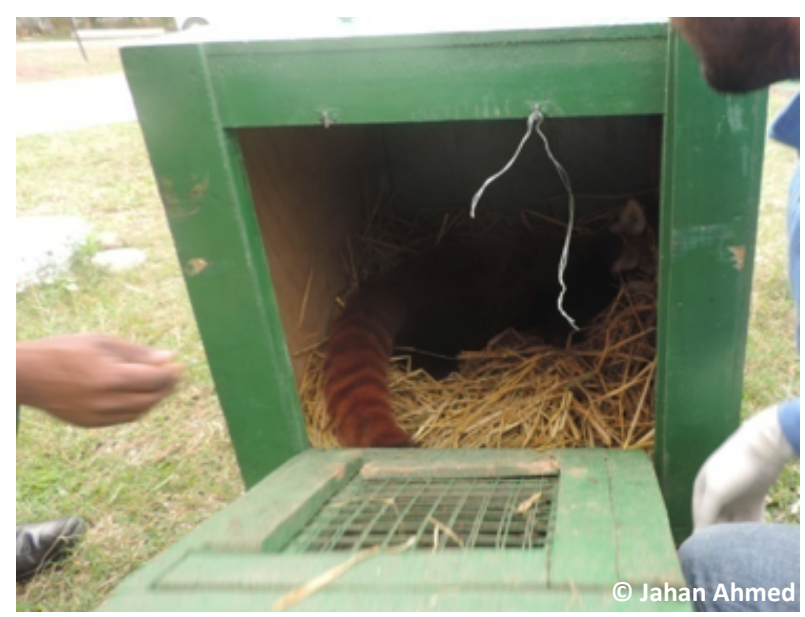

Image 8. Red Panda inside the transportation cage.

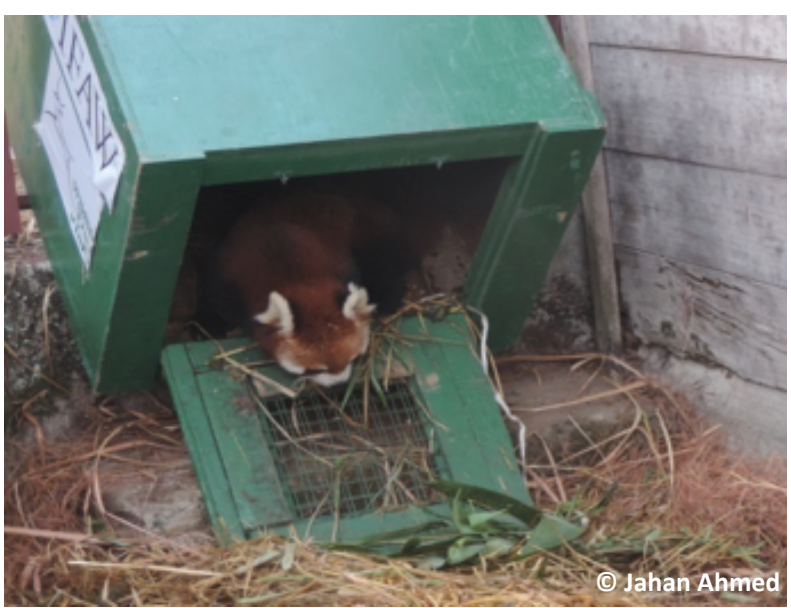

Image 9. Release in Eaglenest Wildlife Sanctuary. health. The confinement of the animal into a dark area during induction of anaesthesia was also suggested by Roberts \& Glatston (1994). This minimizes excitement and stress to the patient, and lowers the amount of anaesthetic drugs required. Dissociative anaesthetics in combination with sedatives or tranquilizers are the choice of anaesthesia for Red Pandas as ketamine $\mathrm{HCl}$ at the dose rate of 11-14 $\mathrm{mg} / \mathrm{kg}$ body weight alone usually results in extreme muscle rigidity and minor Central Nervous System (CNS) stimulations. Hence, ketamine $\mathrm{HCl}$ at the dose rate of $5-10 \mathrm{mg} / \mathrm{kg}$ b.w. in combination with xylazine $\mathrm{HCl}$ at the dose rate of $0.2-0.4 \mathrm{mg} / \mathrm{kg}$ b.w. for immobilization in juvenile and adult Red Pandas was indicated (Wolff et al. 1990; AZA Small Carnivore TAG 2012; Jha 2014). Use of above combinations of anaesthetics and dose rate induced anaesthesia smoothly which was reproducible and found safe. Vital parameters recorded during anaesthesia (Table 2) were in agreement with the observations of Willesen et al. (2012). The physical parameters recorded (Table 3) may be of use for further growth and development studies in captivity. Present physical findings were similar to the observations of previous researchers (Burrell et al. 2018). The haematological and biochemical parameters (Table 4) were in corroboration with the findings of Wolff et al. (1990) for healthy male and female Red Pandas of all age groups indicating the normal physiological activity of the animal. These data may be used as baseline data for rescue and rehabilitation facility managers. In the present study yohimbine $\mathrm{HCl}$ was used @ $0.4 \mathrm{mg} / \mathrm{kg}$ b.w. intramuscularly. Philippa \& Ramsay (2011) recorded that the effects of xylazine $\mathrm{HCl}$ can be reversed with yohimbine $\mathrm{HCl} @ 0.125 \mathrm{mg} / \mathrm{kg}$ b. w. using subcutaneous, intramuscular or intravenous route. There are also reports that yohimbine antagonized the xylazine $\mathrm{HCl}$ portion of ketamine-xylazine $\mathrm{HCl}$ anaesthetic combinations and thereby hastened smooth recovery from anaesthesia in Asiatic Lions, Tigers, and Leopards (Sontakke et al. 2009). The anaesthetic effect was successfully reversed in 14 minutes after the use of reversal indicating the procedure was safe and effective. The animal started normal feeding from the evening of same day and recovered uneventfully.

Combination of ketamine $\mathrm{HCl}$ and xylazine $\mathrm{HCl}$ is frequently used for immobilization, rescue and surgical interventions in wildlife. This paper represents a successful rescue, chemical immobilization for surgical management of head injury, rehabilitation, and translocation of a Red Panda in the Indian state of Arunachal Pradesh. This rescue operation was the first instance record of Red Panda in Yachuli circle, Lower 


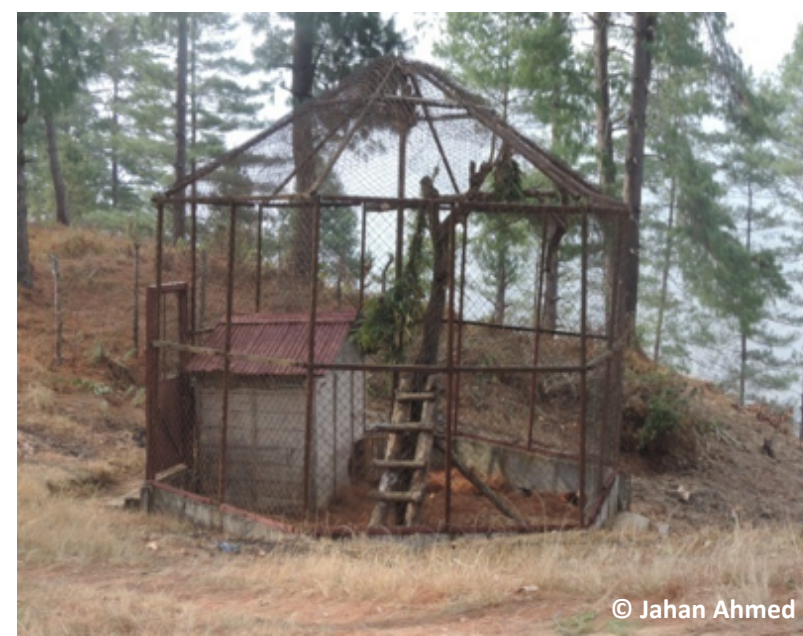

Image 10(a). External view of enclosure.

Subansiri district of Arunachal Pradesh, India.

\section{REFERENCES}

AZA Small Carnivore TAG (2012). Red panda Care Manual. Association of Zoos and Aquariums, Silver Spring, MD, pp. 32-33.

Burrell, C., L. Luo, M.K. Jones, A. Lee, E. Freeman \& C. Aitken-Palmer (2018). Hematology and serum biochemistry values of the Red Panda subspecies (Ailurus fulgens styani). Journal of Zoo and Wildlife Medicine 49(2): 384-395. https://doi.org/10.1638/2017-0104.1

Chakraborty R., L.T. Nahmo, P.K. Dutta, T. Srivastava, K. Mazumdar \& D. Dorji (2015). Status, abundance, and habitat associations of the Red Panda (Ailurus fulgens) in Pangchen Valley, Arunachal Pradesh, India. Mammalia 79(1): 25-32. https://doi.org/10.1515/ mammalia-2013-0105

Choudhury, A. (1996). Red Panda in Garo hills. Environ 4: 21.

Choudhury, A. (1997). Red Panda Ailurus fulgens F. Cuvier in the north-east with an important record from Garo hills. Journal of the Bombay Natural History Society 94: 145-147.

Choudhury, A. (2001). An overview of the status and conservation of the Red Panda Ailurus fulgens in India, with reference to its global status. Oryx 35(3): 250-259. https://doi.org/10.1046/j.13653008.2001.00181.x

Finn, F. (1929). Sterndale's Mammalia of India. Thacker, Spink, Calcutta \& Simla, 347pp.

Glatston, A., F. Wei, T. Zaw \& A. Sherpa (2015). Ailurus fulgens (errata version published in 2017). The IUCN Red List of Threatened Species

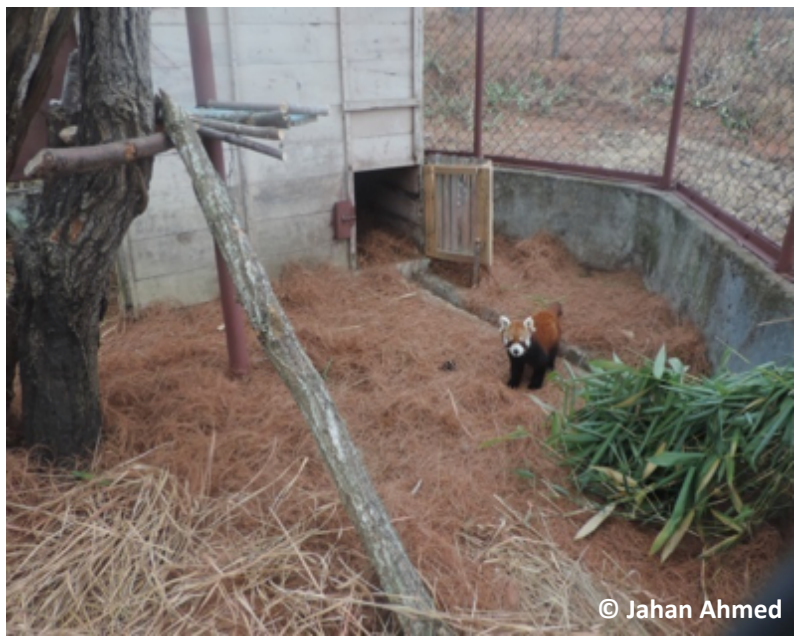

Image 10(b). Internal view of enclosure.

2015:e.T714A110023718. https://doi.org/10.2305/IUCN.UK.20154.RLTS.T714A45195924.en

Gee, E.P. (1964). The Wild Life of India. Collins, London, 192pp.

Jha, A.K. (2014). Working manual of Red Panda conservation breeding programme. Darjeeling, West Bengal, India, 79pp.

Philippa, J. \& E. Ramsay (2011). Captive Red Panda medicine, pp. 271285. In: Glatston, A.R. (ed.). Red Panda: Biology and Conservation of the First Panda. Elsevier, London, 474pp. https://doi.org/10.1016/ B978-1-4377-7813-7.00015-X

Prater, S.H. (1948). The Book of Indian Animals. Bombay Natural History Society, Bombay, 326pp.

Roberts, M. \& A. Glatston (1994). Management and Husbandry Guidelines for Red Panda. As adopted by the AZA Red Panda SSP, Red Panda Studbook, and International Red Panda Management Group. National Zoological Park, Washington, D.C.

Sontakke, S.D., G. Umapathy \& S. Shivaji (2009). Yohimbine antagonizes the anaesthetic effects of ketamine-xylazine in captive Indian wild felids. Veterinary Anaesthesia and Analgesia 36(1): 3441. https://doi.org/10.1111/j.1467-2995.2008.00427.x

Willesen, J.L., F. Meyland-Smith, B. Wiinberg, J. Monrad \& M.F. Bertelsen (2012). Clinical implications of infection with a novel metastrongyloid species in the Red Panda (Ailurus fulgens). Journal of Zoo and Wildlife Medicine 43(2): 283-288. https://doi. org/10.1638/2011-0100.1

Wolff, M.J., A. Bratthauer, D. Fischer, R.J. Montali \& M. Bush (1990). Hematologic and serum chemistry values for the Red Panda (Ailurus fulgens): Variation with sex, age, health status, and restraint. Journal of Zoo and Wildlife Medicine 21: 326-333. 
Dr. John Noyes, Natural History Museum, London, UK

Dr. Albert G. Orr, Griffith University, Nathan, Australia

Dr. Sameer Padhye, Katholieke Universiteit Leuven, Belgium

Dr. Nancy van der Poorten, Toronto, Canada

Dr. Kareen Schnabel, NIWA, Wellington, New Zealand

Dr. R.M. Sharma, (Retd.) Scientist, Zoological Survey of India, Pune, India

Dr. Manju Siliwal, WILD, Coimbatore, Tamil Nadu, India

Dr. G.P. Sinha, Botanical Survey of India, Allahabad, India

Dr. K.A. Subramanian, Zoological Survey of India, New Alipore, Kolkata, India

Dr. P.M. Sureshan, Zoological Survey of India, Kozhikode, Kerala, India

Dr. R. Varatharajan, Manipur University, Imphal, Manipur, India

Dr. Eduard Vives, Museu de Ciències Naturals de Barcelona, Terrassa, Spain

Dr. James Young, Hong Kong Lepidopterists' Society, Hong Kong

Dr. R. Sundararaj, Institute of Wood Science \& Technology, Bengaluru, India

Dr. M. Nithyanandan, Environmental Department, La Ala Al Kuwait Real Estate. Co. K.S.C.,

Kuwait

Dr. Himender Bharti, Punjabi University, Punjab, India

Mr. Purnendu Roy, London, UK

Dr. Saito Motoki, The Butterfly Society of Japan, Tokyo, Japan

Dr. Sanjay Sondhi, TITLI TRUST, Kalpavriksh, Dehradun, India

Dr. Nguyen Thi Phuong Lien, Vietnam Academy of Science and Technology, Hanoi, Vietnam

Dr. Nitin Kulkarni, Tropical Research Institute, Jabalpur, India

Dr. Robin Wen Jiang Ngiam, National Parks Board, Singapore

Dr. Lional Monod, Natural History Museum of Geneva, Genève, Switzerland.

Dr. Asheesh Shivam, Nehru Gram Bharti University, Allahabad, India

Dr. Rosana Moreira da Rocha, Universidade Federal do Paraná, Curitiba, Brasi

Dr. Kurt R. Arnold, North Dakota State University, Saxony, Germany

Dr. James M. Carpenter, American Museum of Natural History, New York, USA

Dr. David M. Claborn, Missouri State University, Springfield, USA

Dr. Kareen Schnabel, Marine Biologist, Wellington, New Zealand

Dr. Amazonas Chagas Júnior, Universidade Federal de Mato Grosso, Cuiabá, Brasil

Mr. Monsoon Jyoti Gogoi, Assam University, Silchar, Assam, India

Dr. Heo Chong Chin, Universiti Teknologi MARA (UiTM), Selangor, Malaysia

Dr. R.J. Shiel, University of Adelaide, SA 5005, Australia

Dr. Siddharth Kulkarni, The George Washington University, Washington, USA

Dr. Priyadarsanan Dharma Rajan, ATREE, Bengaluru, India

Dr. Phil Alderslade, CSIRO Marine And Atmospheric Research, Hobart, Australia

Dr. John E.N. Veron, Coral Reef Research, Townsville, Australia

Dr. Daniel Whitmore, State Museum of Natural History Stuttgart, Rosenstein, Germany.

Dr. Yu-Feng Hsu, National Taiwan Normal University, Taipei City, Taiwan

Dr. Keith V. Wolfe, Antioch, California, USA

Dr. Siddharth Kulkarni, The Hormiga Lab, The George Washington University, Washington,

D.C., USA

Dr. Tomas Ditrich, Faculty of Education, University of South Bohemia in Ceske

Budejovice, Czech Republic

Dr. Mihaly Foldvari, Natural History Museum, University of Oslo, Norway

Dr. V.P. Uniyal, Wildlife Institute of India, Dehradun, Uttarakhand 248001, India

Dr. John T.D. Caleb, Zoological Survey of India, Kolkata, West Bengal, India

Dr. Priyadarsanan Dharma Rajan, Ashoka Trust for Research in Ecology and the Environment

(ATREE), Royal Enclave, Bangalore, Karnataka, India

\section{Fishes}

Dr. Neelesh Dahanukar, IISER, Pune, Maharashtra, India

Dr. Topiltzin Contreras MacBeath, Universidad Autónoma del estado de Morelos, México

Dr. Heok Hee Ng, National University of Singapore, Science Drive, Singapore

Dr. Rajeev Raghavan, St. Albert's College, Kochi, Kerala, India

Dr. Robert D. Sluka, Chiltern Gateway Project, A Rocha UK, Southall, Middlesex, UK

Dr. E. Vivekanandan, Central Marine Fisheries Research Institute, Chennai, India

Dr. Davor Zanella, University of Zagreb, Zagreb, Croatia

Dr. A. Biju Kumar, University of Kerala, Thiruvananthapuram, Kerala, India

Dr. Akhilesh K.V., ICAR-Central Marine Fisheries Research Institute, Mumbai Research

Centre, Mumbai, Maharashtra, India

Dr. J.A. Johnson, Wildlife Institute of India, Dehradun, Uttarakhand, India

Amphibians

Dr. Sushil K. Dutta, Indian Institute of Science, Bengaluru, Karnataka, India

Dr. Annemarie Ohler, Muséum national d'Histoire naturelle, Paris, France

\section{Reptiles}

Dr. Gernot Vogel, Heidelberg, Germany

Dr. Raju Vyas, Vadodara, Gujarat, India

Dr. Pritpal S. Soorae, Environment Agency, Abu Dubai, UAE.

Prof. Dr. Wayne J. Fuller, Near East University, Mersin, Turkey

Prof. Chandrashekher U. Rivonker, Goa University, Taleigao Plateau, Goa. India

Dr. S.R. Ganesh, Chennai Snake Park, Chennai, Tamil Nadu, India

Dr. Himansu Sekhar Das, Terrestrial \& Marine Biodiversity, Abu Dhabi, UAE
Birds

Dr. Hem Sagar Baral, Charles Sturt University, NSW Australia

Dr. Chris Bowden, Royal Society for the Protection of Birds, Sandy, UK

Dr. Priya Davidar, Pondicherry University, Kalapet, Puducherry, India

Dr. J.W. Duckworth, IUCN SSC, Bath, UK

Dr. Rajah Jayapal, SACON, Coimbatore, Tamil Nadu, India

Dr. Rajiv S. Kalsi, M.L.N. College, Yamuna Nagar, Haryana, India

Dr. V. Santharam, Rishi Valley Education Centre, Chittoor Dt., Andhra Pradesh, India

Dr. S. Balachandran, Bombay Natural History Society, Mumbai, India

Mr. J. Praveen, Bengaluru, India

Dr. C. Srinivasulu, Osmania University, Hyderabad, India

Dr. K.S. Gopi Sundar, International Crane Foundation, Baraboo, USA

Dr. Gombobaatar Sundev, Professor of Ornithology, Ulaanbaatar, Mongolia

Prof. Reuven Yosef, International Birding \& Research Centre, Eilat, Israel

Dr. Taej Mundkur, Wetlands International, Wageningen, The Netherlands

Dr. Carol Inskipp, Bishop Auckland Co., Durham, UK

Dr. Tim Inskipp, Bishop Auckland Co, Durham, UK

Dr. V. Gokula, National College, Tiruchirappalli, Tamil Nadu, India

Dr. Arkady Lelej, Russian Academy of Sciences, Vladivostok, Russia

Dr. Simon Dowell, Science Director, Chester Zoo, UK

Dr. Mário Gabriel Santiago dos Santos, Universidade de Trás-os-Montes e Alto Douro,

Quinta de Prados, Vila Real, Portugal

Dr. Grant Connette, Smithsonian Institution, Royal, VA, USA

Dr. M. Zafar-ul Islam, Prince Saud Al Faisal Wildlife Research Center, Taif, Saudi Arabia

Mammals

Dr. Giovanni Amori, CNR - Institute of Ecosystem Studies, Rome, Italy

Dr. Anwaruddin Chowdhury, Guwahati, India

Dr. David Mallon, Zoological Society of London, UK

Dr. Shomita Mukherjee, SACON, Coimbatore, Tamil Nadu, India

Dr. Angie Appel, Wild Cat Network, Germany

Dr. P.O. Nameer, Kerala Agricultural University, Thrissur, Kerala, India

Dr. Ian Redmond, UNEP Convention on Migratory Species, Lansdown, UK

Dr. Heidi S. Riddle, Riddle's Elephant and Wildlife Sanctuary, Arkansas, USA

Dr. Karin Schwartz, George Mason University, Fairfax, Virginia.

Dr. Lala A.K. Singh, Bhubaneswar, Orissa, India

Dr. Mewa Singh, Mysore University, Mysore, India

Dr. Paul Racey, University of Exeter, Devon, UK

Dr. Honnavalli N. Kumara, SACON, Anaikatty P.O., Coimbatore, Tamil Nadu, India

Dr. Nishith Dharaiya, HNG University, Patan, Gujarat, India

Dr. Spartaco Gippoliti, Socio Onorario Società Italiana per la Storia della Fauna "Giuseppe

Altobello", Rome, Italy

Dr. Justus Joshua, Green Future Foundation, Tiruchirapalli, Tamil Nadu, India

Dr. H. Raghuram, The American College, Madurai, Tamil Nadu, India

Dr. Paul Bates, Harison Institute, Kent, UK

Dr. Jim Sanderson, Small Wild Cat Conservation Foundation, Hartford, USA

Dr. Dan Challender, University of Kent, Canterbury, UK

Dr. David Mallon, Manchester Metropolitan University, Derbyshire, UK

Dr. Brian L. Cypher, California State University-Stanislaus, Bakersfield, CA

Dr. S.S. Talmale, Zoological Survey of India, Pune, Maharashtra, India

Prof. Karan Bahadur Shah, Budhanilakantha Municipality, Kathmandu, Nepal

Dr. Susan Cheyne, Borneo Nature Foundation International, Palangkaraja, Indonesia

Dr. Hemanta Kafley, Wildlife Sciences, Tarleton State University, Texas, USA

\section{Other Disciplines}

Dr. Aniruddha Belsare, Columbia MO 65203, USA (Veterinary)

Dr. Mandar S. Paingankar, University of Pune, Pune, Maharashtra, India (Molecular)

Dr. Jack Tordoff, Critical Ecosystem Partnership Fund, Arlington, USA (Communities)

Dr. Ulrike Streicher, University of Oregon, Eugene, USA (Veterinary)

Dr. Hari Balasubramanian, EcoAdvisors, Nova Scotia, Canada (Communities)

Dr. Rayanna Hellem Santos Bezerra, Universidade Federal de Sergipe, São Cristóvão, Brazil

Dr. Jamie R. Wood, Landcare Research, Canterbury, New Zealand

Dr. Wendy Collinson-Jonker, Endangered Wildlife Trust, Gauteng, South Africa

Dr. Rajeshkumar G. Jani, Anand Agricultural University, Anand, Gujarat, India

Dr. O.N. Tiwari, Senior Scientist, ICAR-Indian Agricultural Research Institute (IARI), New

Delhi, India

Dr. L.D. Singla, Guru Angad Dev Veterinary and Animal Sciences University, Ludhiana, India

Dr. Rupika S. Rajakaruna, University of Peradeniya, Peradeniya, Sri Lanka

Dr. Bahar Baviskar, Wild-CER, Nagpur, Maharashtra 440013, India

Reviewers 2018-2020

Due to pausity of space, the list of reviewers for $2018-2020$ is available online.

The opinions expressed by the authors do not reflect the views of the Journal of Threatened Taxa, Wildlife Information Liaison Development Society, Zoo Outreach Organization, or any of the partners. The journal, the publisher, the host, and the partners are not responsible for the accuracy of the political boundaries shown in the maps by the authors.

Journal of Threatened Taxa is indexed/abstracted in Bibliography of Systematic Mycology, Biological Abstracts, BIOSIS Previews, CAB Abstracts, EBSCO, Google Scholar, Index Copernicus, Index Fungorum, JournalSeek, National Academy of Agricultural Sciences, NewJour, OCLC WorldCat, SCOPUS, Stanford University Libraries, Virtual Library of Biology, Zoological Records.

NAAS rating (India) 5.64
Print copies of the Journal are available at cost. Write to:

The Managing Editor, JoTT,

c/o Wildlife Information Liaison Development Society,

No. 12, Thiruvannamalai Nagar, Saravanampatti - Kalapatti Road,

Saravanampatti, Coimbatore, Tamil Nadu 641035, India

ravi@threatenedtaxa.org 


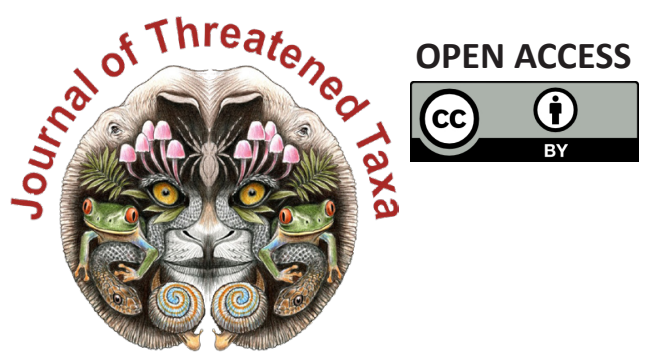

www.threatenedtaxa.org

The Journal of Threatened Taxa (JoTT) is dedicated to building evidence for conservation globally by publishing peer-reviewed articles online every month at a reasonably rapid rate at www.threatenedtaxa.org. All articles published in JoTT are registered under Creative Commons Attribution 4.0 International License unless otherwise mentioned. JoTT allows allows unrestricted use, reproduction, and distribution of articles in any medium by providing adequate credit to the author(s) and the source of publication.

ISSN 0974-7907 (Online) I ISSN $0974-7893$ (Print)

\section{November 2021 | Vol. 13 | No. 13 | Pages: 19887-20142 \\ Date of Publication: 26 November 2021 (Online \& Print) DOI: 10.11609/jott.2021.13.13.19887-20142}

\section{Article}

An inventory of geometrid moths (Lepidoptera: Geometroidea: Geometridae) of KalakadMundanthurai Tiger Reserve, India

- Geetha Iyer, Dieter Stüning \& Sanjay Sondhi, Pp. 19887-19920

\section{Communications}

Roadkills of Lowland Tapir Tapirus terrestris (Mammalia: Perissodactyla: Tapiridae) in one of its last refuges in the Atlantic Forest

- Aureo Banhos, Andressa Gatti, Marcelo Renan de Deus Santos, Leonardo Merçon,

Ilka Westermeyer, Natália Carneiro Ardente, Luis Francisco Oliveira Pereira Gonzaga, Lucas Mendes Barreto, Lucas Damásio, Tomas Lima Rocha, Vitor Roberto Schettino, Renata Valls, Helena Godoy Bergallo, Marcos Vinicius Freitas Silva, Athelson Stefanon Bittencourt, Danielle de Oliveira Moreira \& Ana Carolina Srbek-Araujo, Pp. 19921-19929

Scientific contributions and learning experiences of citizen volunteers with a small cat project in Sanjay Gandhi National Park, Mumbai, India

- Shomita Mukherjee, R. Nandini, P.V. Karunakaran \& Nayan Khanolkar, Pp. 19930-19936

Seasonal food preferences and group activity pattern of Blackbuck Antilope cervicapra (L., 1758) (Mammalia: Cetartiodactyla: Bovidae) in a semi-arid region of western Haryana, India

- Vikram Delu, Dharambir Singh, Sumit Dookia, Priya \& Kiran, Pp. 19937-19947

Studies on the habitats of Grey Francolin Francolinus pondicerianus (J.F. Gmelin, 1789) (Galliformes: Phasianidae) in northern districts of Tamil Nadu, India

- M. Pandian, Pp. 19948-19955

Recovery of vulture population in roosting and scavenging areas of Bastar and Bijapur, Chhattisgarh, India

- Sushil Kumar Dutta, Muntaz Khan, P.R.S. Nagi, Santosh Durgam \& Surabhi Dutta, Pp. 19956-19963

A geographical assessment of Chariganga and Arpara Beel (wetlands) of Nadia, West Bengal as a habitat of wetland birds

- Mehedi Hasan Mandal, Arindam Roy \& Giyasuddin Siddique, Pp. 19964-19975

Phenotypic plasticity in Barilius vagra (Hamilton, 1822) (Teleostei: Danionidae) from two geographically distinct river basins of Indian Himalaya

- Sumit Kumar, Sharali Sharma \& Deepak Singh, Pp. 19976-19984

Taxonomic notes, a new species, and a key to Indian species of the click beetle genus Cryptalaus Ôhira, 1967 (Coleoptera: Elateridae: Agrypninae)

- Harshad Parekar \& Amol Patwardhan, Pp. 19985-19999

Niche overlap of benthic macrofauna in a tropical estuary: diurnal variation

- Mário Herculano de Oliveira, Lidiane Gomes de Lima, Caroline Stefani da Silva Lima, Jéssica de Oliveira Lima Gomes, Franciely Ferreira Paiva, Graciele de Barros, Carlinda Railly Medeiros \& Joseline Molozzi, Pp. 20000-20010

Diversity of aquatic insects and biomonitoring of water quality in the upper Ganga River, a Ramsar site: a preliminary assessment

- Kritish De, Arkojyoti Sarkar, Kritika Singh, Virendra Prasad Uniyal, Jeyaraj Antony Johnson \& Syed Ainul Hussain, Pp. 20011-20018

Patterns of forest cover loss in the terrestrial Key Biodiversity Areas in the Philippines: critical habitat conservation priorities

- Bernard Peter O. Daipan, Pp. 20019-20032

The woody flora of Shettihalli Wildlife Sanctuary, central Western Ghats of Karnataka, India - A checklist

- Kanda Naveen Babu, Kurian Ayushi, Vincy K. Wilson, Narayanan Ayyappan \&

Narayanaswamy Parthasarathy, Pp. 20033-20055

Reproductive biology of Ophiorrhiza caudata C.E.C.Fisch. (Rubiaceae), an endemic and endangered creeping perennial herb of the Western Ghats, India

- Maria Theresa, Appukuttan Kamalabai Sreekala \& Jayalakshmi Mohanlal, Pp. 20056-20065
Short Communications

Successful rescue, medical management, rehabilitation, and translocation of a Red Panda Ailurus fulgens (Mammalia: Carnivora: Ailuridae) in Arunachal Pradesh, India - Jahan Ahmed, Sorang Tadap, Millo Tasser, Koj Rinya, Nekibuddin Ahmed \& Sunil Kyarong, Pp. 20066-20071

A rare photographic record of Eurasian Otter Lutra lutra with a note on its habitat from the Bhagirathi Basin, western Himalaya, India

- Ranjana Pal, Aashna Sharma, Vineet Kumar Dubey, Tapajit Bhattacharya, Jeyaraj Antony Johnson, Kuppusamy Sivakumar \& Sambandam Sathyakumar, Pp. 20072-20077

The first record of Medog Gliding Frog Rhacophorus translineatus Wu, 1977 (Anura: Rhacophoridae) from Chhukha District, Bhutan

- Sonam Lhendup \& Bal Krishna Koirala, Pp. 20078-20083

First record of a freshwater crab, Maydelliathelphusa masoniana (Henderson, 1893) (Decapoda: Brachyura: Gecarcinucidae) from West Bengal, India

- Ram Krishna Das, Pp. 20084-20089

Butterflies of Amrabad Tiger Reserve, Telangana, India

- Deepa Jaiswal, B. Bharath, M. Karuthapandi, Shrikant Jadhav, S. Prabakaran \& S. Rehanuma Sulthana, Pp. 20090-20097

An enumeration of the flowering plants of Kyongnosla Alpine Sanctuary in eastern Sikkim, India

- Sudhansu Sekhar Dash, Subhajit Lahiri \& Ashiho Asoshii Mao, Pp. 20098-20117

A new record of psychrotrophic Paecilomyces formosus (Eurotiales: Ascomycota) from India: morphological and molecular characterization

- Skarma Nonzom \& Geeta Sumbali, Pp. 20118-20123

Notes

Study on incidence and pathology of gastrointestinal parasitic infections in Nilgai Boselaphus tragocamelus in Hisar, Haryana, India

- Maneesh Sharma, B.L. Jangir, D. Lather, G.A. Chandratre, V. Nehra, K.K. Jakhar \& G. Narang, Pp. 20124-20127

An unusual vocalization of Brown Hawk-Owl Ninox scutulata (Raffles, 1822) (Aves:

Strigiformes: Strigidae) recorded from Kerala, India

- Riju P. Nair \& Shine Raj Tholkudiyil, Pp. 20128-20129

New distribution data on the genus Maripanthus Maddison, 2020 (Araneae: Salticidae) from southern India

- A. Asima, John T.D. Caleb, Dhruv A. Prajapati \& G. Prasad, Pp. 20130-20132

On the IUCN status of Boesenbergia albolutea and B. rubrolutea (Zingiberaceae) and typification of $B$. rubrolutea

- K. Aishwarya \& M. Sabu, Pp. 20133-20135

New records of mass seeding Cephalostachyum latifolium Munro (Poaceae) along the midelevation broadleaved forest of Sarpang district, Bhutan

- Jigme Tenzin, Sangay Nidup \& Dago Dorji, Pp. 20136-20139

Response

If habitat heterogeneity is effective for conservation of butterflies in urban landscapes of Delhi, India?' Unethical publication based on data manipulation

- Sanjay Keshari Das \& Rita Singh, Pp. 20140-20142

Publisher \& Host
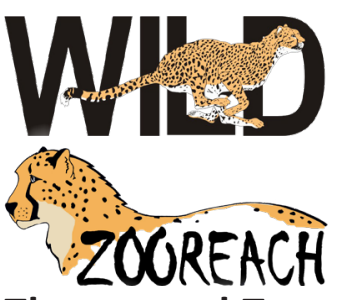

Threatened Taxa 